\title{
ZDRAVSTVENI NADZOR VODOVODA OPĆINE LIVNO
}

\author{
Stipe Čelan ${ }^{1}$, Zora Pilić ${ }^{2}$ \\ ${ }^{1}$ Fakultet zdravstvenih studija, Bijeli Brijeg bb, 88000 Mostar \\ ${ }^{2}$ Fakultet prirodoslovnih matematičkih i odgojnih znanosti, Matice hrvatske bb, 88000 Mostar \\ Rad je primljen: 5.10.2015. \\ Rad je revidiran: 19.10.2015. \\ Rad je prihvaćen: 1.11.2015.
}

\section{SAŽETAK}

UVOD: Zdravstveni nadzor voda za piće obuhvaća: lokalni pregled i održavanje vodovodnih objekata, fizikalno-kemijske i mikrobiološke analize. Za primjer provedbe zdravstvenog nadzora uzet je vodovod Općine Livno.

CILJ RADA: Prikazati važnost i značaj provedbe zdravstvenog nadzora na primjeru vodovoda Općine Livno.

MATERIJALI I METODE: Rad je napisan retrospektivnim istraživanjem, na osnovu fizikalno-kemijskih i mikrobioloških analiza vode za piće vodovoda Općine Livno. Analize se odnose na period 1.1.2013-1.1.2014.

REZULTATI: Fizikalno-kemijski parametri od samog izvorišta pa do krajnje točke vodoopskrbnog sustava su uredni i gotovo identični. Većina mikrobioloških uzoraka uzetih na samom izvorištu (sirova voda) koja nije dezinficirana, mikrobiološki je pozitivna što predstavlja trajnu opasnost od kontaminacije. Nakon procesa dezinfekcije svi uzorci uzeti tokom godine iz gradske slavine su imali vrijednosti ispitivanih parametara u dozvoljenim koncentracijama.

ZAKLJUČAK: Vodovod Općine Livno prikazuje ispravan primjer zdravstvenog nadzora voda za piće.

KLJUČNE RIJEČI: Zdravstveni nadzor, vodovod općine Livno

Osoba za razmjenu informacija:

Stipe Čelan, prvostupnik sanitarnog inženjerstva

stipecelan@gmail.com

\section{UVOD}

Voda je dio čovjeka i njegovog života, osnova tehnološkog, kulturološkog i civilizacijskog napretka. Voda je važan ekonomski resurs koji je, nažalost ograničen. Drevne civilizacije su nastajale i razvijale se na područjima koja su obilovala velikim količinama vode, a koju je bilo moguće regulirati i iskoristiti za svakodnevne potrebe. Za moderno ljudsko društvo voda je nezamjenjiv prirodni resurs. Uporaba vode $u$ današnjem vremenu ogleda se $u$ nekoliko privrednih i društvenih sfera: razvoj intenzivne poljoprivredne proizvodnje, osnovna ili pomoćna komponenta mnogih tehnoloških procesa. Velike količine vode troše se u procesu proizvodnje električne energije, razvoj marikulture, te $u$ mnogim drugim društvenim aktivnostima kao što su sport i rekreacija. Brzi rast stanovništva usporedno prati i eksponencijalni rast potrošnje vode. Osiguravanje dovoljne i ravnomjerno raspoređene količine zdravstveno-higijenski ispravne vode za piće nesumnjivo postaje globalni svjetski problem broj jedan (1).
Kao „uzorak“ na kojem će se promatrati provedba zdravstvenog nadzora uzet je vodovod Općine Livno sa izvorištem Duman (Bistrica). Izvor predstavlja strateški vodoopskrbni potencijal općine Livno. Zdravstveni nadzor voda za piće provodi se na dvije razine. Prvu razinu čini djelatno osoblje Javno poduzeće komunalno (JPK) Livno koje je izravno vezano za distribuciju vode navedenog izvorišta i održavanje vodovodnog sustava. Drugu razinu čini ovlaštena ustanova, odnosno laboratorij Zavoda za javno zdravstvo (ZZJZ) Hercegbosanske županije u kojem se rade fizikalno-kemijske i mikrobiološke analize. Fizikalno-kemijskim analizama utvrđuju se: temperatura, miris, okus, mutnoća, $\mathrm{pH}$ vrijednost, provodljivost, nitrati, željezo, klor te prisutnost drugih tvari. Mikrobiološkim analizama otkriva se prisutnost patogenih mikroorganizama. Cilj rada je prikazati važnost i značaj provedbe zdravstvenog nadzora koji uključuje lokalni pregled i održavanje vodovodnih objekata i provedbu obaveznih 
fizikalno-kemijskih i mikrobioloških analiza koje služe za detekciju onečišćenja.

\section{MATERIJALI I METODE}

\section{Materijali}

U provođenju fizikalno-kemijskih i bakterioloških istraživanja određenog vodnog potencijala, sudjeluju akreditirane ustanove, koje su ovlaštene od strane državnog tijela (određenog ministarstva) da mogu obavljati navedene poslove. U ovom radu korištene su analize voda, koje se redovito provode u Zavodu za javno zdravstvo Hercegbosanske županije, a koje su propisane Pravilnikom o zdravstvenoj ispravnosti vode za piće (2). Kako bi se opisalo izvorište i vodoopskrbni sustav korišteni su podatci iz Dokumenta strategije razvoja općine Livno (3). Rad je napisan na temelju retrospektivnog istraživanja, na osnovu fizikalno-kemijskih i mikrobioloških analiza vode za piće vodovoda Općine Livno. Analize se odnose na period 1.1.2013.-1.1.2014. godine.

\section{Parametri istraživanja i metode prikupljanja podataka}

Promatrani su fizikalno kemijski i mikrobiološki parametri koji su propisani Pravilnikom o zdravstvenoj ispravnosti vode za piće (2). Korištene su analize iz 2013. godine Zavoda za javno zdravstvo Hercegbosanske županije, koje su evidentirane i pohranjene u ZZJZ HBŽ. Prikupljeni podatci su obrađeni u programu Microsoft Office Word 2003 (Microsoft Corporation, redmond WA, SA.) i Microsoft Excell 2003 (Microsoft Corporation, redmond WA, SA).

\section{Fizikalno-kemijske analize}

Miris i okus- određeni su ljudskim osjetilom mirisa i okusa i opisuju se usporedno s poznatim mirisima i okusima.

Temperatura- mjerenje provedeno korištenjem standardnog termometra.

$\mathrm{pH}$ - vrijednost $\mathrm{pH}$ je izmjerena $\mathrm{pH}$ metrom Comparator.

Boja vode-određena opisno.

Električna provodnost- izmjerena je instrumentom Conductiviy Meter LF 538.
Klor-mjerenje provedeno Heling komparatorom.

\section{Mikrobiološke analize}

Postupak membranske filtracije provodi se tako da se određeni volumen istraživanog uzorka vode $(100 \mathrm{ml})$ uz pomoć vakuum pumpe profiltrira kroz specijalni membranski filtar veličine pora $0,2-0,45 \mu \mathrm{m}$. Sve bakterijske vrste koje su nazočne $\mathrm{u}$ istraživanom uzorku vode zaostaju na površini filtra. Nakon toga filtar se vadi iz lijevka i odlaže u petrijeve posude. Petrijeve posude su pripremljene tako da se u njima nalazi hranjiva podloga (Endo agar) koja je namijenjena za rast isključivo koliformnih bakterija. Inkubacija se odvija na $35-37^{\circ} \mathrm{C}$. Rezultati analiza predstavljaju prisutan broj koliformnih bakterija na filtar papiru (1).

\section{REZULTATI}

\section{Fizikalno-kemijske analize}

$\mathrm{Na}$ vodoopskrbnom sustavu izvorišta Duman (Bistrica) 2013. godine redovito su se provodile fizikalno-kemijske i mikrobiološke analize. Svi fizikalno-kemijski parametri od samog izvorišta pa do krajnje točke vodoopskrbnog sustava su uredni i gotovo identični. U ovom radu uzeti su rezultati fizikalno-kemijskih analiza koji su rađeni tokom godine i određene su prosječne vrijednosti koje su u granicama dopuštenih vrijednosti (tablica 1)

Tablica 1. Prosječne vrijednosti fizikalno-kemijskih parametara

\begin{tabular}{lccc}
\hline \multicolumn{1}{c}{ Analizirani } & Jedinica & Rezultat & MDK \\
\hline Temperatura & $\circ$ & 10,1 & 25 \\
Okus & bez & bez & bez \\
Miris & bez & bez & bez \\
Boja & bez & bez & bez \\
pH & - & 7.5 & $6.5-8.5$ \\
Mutnoća & - & 0.00 & 4 \\
Vodliivost & $\mu S / c m$ & 250 & 2500 \\
Klor & $\mathrm{mg} / \mathrm{l}$ & 0.3 & 0.5 \\
\hline
\end{tabular}

(MDK- Maksimalno dopuštena koncentraciia)

\section{Mikrobiološke analize}

Većina uzoraka uzetih na samom izvorištu (sirova voda) koja nije obrađena (dezinficirana), mikrobiološki je pozitivna, što se može vidjeti iz tablica 2.-4. 
Tablica 2. Rezultati analize uzorka sirove vode, 27.3.2013. godine

\begin{tabular}{lccc}
\hline $\begin{array}{c}\text { Vrsta } \\
\text { mikroorganizama }\end{array}$ & $\begin{array}{c}\text { Rezultati u ml } \\
\text { uzorka }\end{array}$ & Rezultati & $\begin{array}{c}\text { Pročiš́ena voda za } \\
\text { piće MDK }\end{array}$ \\
\hline Koliformne bakterije & $100 \mathrm{MF}$ & $<100$ & 10 \\
Fekalne koliformne & $100 \mathrm{MF}$ & $>0$ & 0 \\
Escherichia coli & $100 \mathrm{MF}$ & $>0$ & 0 \\
\hline
\end{tabular}

(MDK-Maksimalno dopuštena koncentracija, MF- Metoda membranske filtraciie)

Tablica 3. Rezultati analize uzorka sirove vode, 31.5.2013. godine

\begin{tabular}{lccc}
\hline $\begin{array}{c}\text { Vrsta } \\
\text { mikroorganizama }\end{array}$ & $\begin{array}{c}\text { Rezultati u ml } \\
\text { Uzorka }\end{array}$ & Rezultati & $\begin{array}{c}\text { Pročiš́cena voda za } \\
\text { piće MDK }\end{array}$ \\
\hline Koliformne bakterije & $100 \mathrm{MF}$ & $<100$ & 10 \\
Fekalne koliformne & $100 \mathrm{MF}$ & 0 & 0 \\
Escherichia coli & $100 \mathrm{MF}$ & $>0$ & 0 \\
\hline (MDK-Maksimalno dopuštena koncentracija, MF- Metoda membranske filtraciie)
\end{tabular}

Tablica 4. Rezultati analize uzorka sirove vode, 30.8.2013. godine

\begin{tabular}{lccc}
\hline $\begin{array}{c}\text { Vrsta } \\
\text { mikroorganizama }\end{array}$ & $\begin{array}{c}\text { Rezultati u ml } \\
\text { uzorka }\end{array}$ & Rezultati & $\begin{array}{c}\text { Pročišcena voda za } \\
\text { piće MDK }\end{array}$ \\
\hline Koliformne bakterije & $100 \mathrm{MF}$ & $<100$ & 10 \\
Fekalne koliformne & $100 \mathrm{MF}$ & $>0$ & 0 \\
Escherichia coli & $100 \mathrm{MF}$ & $>0$ & 0 \\
\hline
\end{tabular}

(MDK-Maksimalno dopuštena koncentracija, MF- Metoda membranske filtraciie)

Nakon procesa dezinfekcije svi uzorci uzeti tokom godine iz gradske slavine (slavina koja je smještena u centru grada, priključena je na gradski vodovod i koristi se za piće) su imali vrijednosti ispitivanih parametara u dozvoljenim koncentracijama. Nema mikrobioloških odstupanja (tablica 5.).

Tablica 5. Prosječne vrijednosti mikrobioloških parametara

\begin{tabular}{lccc}
\hline $\begin{array}{c}\text { Vrsta } \\
\text { mikroorganizama }\end{array}$ & $\begin{array}{c}\text { Rezultati u ml } \\
\text { uzorka }\end{array}$ & Rezultati & $\begin{array}{c}\text { Pročišcena voda za } \\
\text { piće MDK }\end{array}$ \\
\hline Koliformne bakterije & $100 \mathrm{MF}$ & 0 & 10 \\
Fekalne koliformne & $100 \mathrm{MF}$ & 0 & 0 \\
Escherichia coli & $100 \mathrm{MF}$ & 0 & 0 \\
\hline
\end{tabular}

(MDK-Maksimalno dopuštena koncentracija, MF- Metoda membranske filtraciie)

\section{RASPRAVA}

Sanitarno-tehničko stanje vodovodnih sustava izravno je vezano sa zdravstveno-higijenskim stanjem vode za piće. U postupku proizvodnje i distribucije vode sanitarna zaštita je jedan od najvažnijih segmenata.

Uzorci uzeti na samom izvorištu Duman (sirova voda) koja nije obrađena (dezinficirana), mikrobiološki je pozitivna, što se može vidjeti iz tablica (4.2.4.4.). To je karakteristično za vode krškog područja zbog nemogućnosti prirodne filtracije. Ovakva situacija predstavlja potencijalnu i stalnu opasnost od onečišćenja vode patogenim mikroorganizmima (1). Zbog toga se mora obratiti posebna pozornost na pravilan zdravstveno-higijenski nadzor, da bi se osiguralo kontinuirano i kvalitetno opskrbljivanje vodom, a u samom procesu potrebno je pratiti opskrbu vodom od samog izvorišta pa do krajnjeg potrošača.

Vodovodni sustav kao cjelina je kompleksan sklop velikog broja objekata, na velikom području. Dug je put vode od izvorišta do najudaljenijih potrošača. Svi ti prostori na kojima su izgrađeni ovi objekti pod stalnim su utjecajem životne sredine. Zbog toga se mora obratiti posebna pozornost na pravilno funkcioniranje i održavanje, da bi se osiguralo kontinuirano i kvalitetno opskrbljivanje vodom (4).

Sanitarna zaštita i praćenje kvaliteta vode u centraliziranom vodovodnom sustavu provodi se od strane stručnih službi, da bi se vodovodni sustav zaštitio od svih mogućih oblika kontaminacije (fizičkih, kemijskih i mikrobioloških).

Zahvatni objekt je dobro fizički zaštićen i osiguran od mogućnosti prodora površinskih voda. Dovodni cjevovodi se stalno kontroliraju. Analize uzorkovanja sirove vode većinom pokazuju mikrobiološku kontaminaciju.

Vodozahvatna crpna stanica opremljena je modernim postrojenjem koje ima funkciju usisavanja zahvaćene vode na izvorištu i potiskivanje iste ka rezervoarnim spremnicima kojih ima sedam, a služe za prihvat i distribuciju vode u vodoopskrbnu mrežu. Postrojenje je opremljeno i s modernim automatskim postrojenjem za provođenjem procesa dezinfekcije vode. To je plinski klorinator koji dozira određenu količinu klora u sirovu vodu . Kao sredstvo koristi se čisti klor u plinovitom stanju koji se čuva u čeličnim bocama pri tlaku od 10 bara $(1,3)$. 
Prilikom dodavanja klora vodi, dio klora se troši na oksidaciju organskih tvari prisutnih u vodi, uključujući i mikroorganizme, kao i na oksidaciju željeza i mangana prisutnih u vodi. Doza klora koja se dodaje vodi predstavlja sumu količine klora koji je potreban da bi se izvršio proces dezinfekcije i rezidualnog klora. Rezidualni klor predstavlja koncentraciju klora izraženu u mg/l koja zaostaje u vodi kao višak nakon reakcije klora s tvarima koje se mogu oksidirati. Zakonski dozvoljena koncentracija klora u vodi iznosi do $0,5 \mathrm{mg} / \mathrm{l}$ (5).

Nakon dezinfekcije provodi se fizikalno-kemijska analiza, s ciljem utvrđivanja rezidualnog klora. Uzorak se uzima od samog početka distribucije vode, rezervoarskih komora pa do najudaljenijeg mjesta.

Prosječna koncentracija rezidualnog klora nakon dezinfekcije iznosi $0.3 \mathrm{mg} / \mathrm{l}$. Nakon toga voda ide u distribuciju. Svi uzorci za mikrobiološku analizu nakon provedene dezinfekcije su negativni, voda je zdravstveno ispravna. Mikrobiološki i fizikalno-kemijski parametri su u granicama dopuštenih vrijednosti (tablice 4.1. i 4.5.).

Prikaz zdravstvenog nadzora vodovodnog sustava Općine Livno može poslužiti kao izvrstan primjer kako se od samog izvorišta pa do krajnjeg potrošača osigurava zdravstveno ispravna voda za piće (6).

\section{ZAKLJUČCI}

Vodovod Općine Livno prikazuje ispravan primjer zdravstvenog nadzora voda za piće. Zdravstveni nadzor provodi se na dvije razine.
Prvu razinu čini djelatno osoblje JPK Livno koje je izravno vezano za distribuciju vode navedenog izvorišta i osposobljeno u smislu uspješnog provođenja postupaka dezinfekcije vodoopskrbnog sustava i angažman ovlaštene ustanove JPK Livno koja provodi kompletan nadzor nad navedenim vodoopskrbnim sustavom.

Drugu razinu čini ustanova, odnosno laboratorij ZZJZ Hercegbosanske županije u kojem se analiziraju uzorci i koja posjeduje sustav analitičke kontrole kvalitete. Ove dvije službe zajedno omogućavaju sigurnu preradu i distribuciju zdravstveno ispravne vode za piće.

\section{LITERATURA}

1. Perković Z. Tehnologija vode, Veleučilište Knin, Knin 2011.

2. Službeni glasnik BiH: Pravilnik o izmjenama i dopunama pravilnika o zdravstvenoj ispravnosti vode za piće. 174.2012.

3. Dokument strategije razvoja općine Livno, Livno 2011.

4. Valić F. Zdravstvena ekologija, Medicinska naklada Zagreb, 2001.

5. Pilić Z, Buntić N, Mišković I. Tehnologija i analiza voda, Interna skripta, FPMOZ, Mostar, 2013.

6. Čelan S. Završni rad, Fakultet zdravstvenih studija, Mostar, 2014. 


\title{
HEALTH SURVEILLANCE OF LIVNO MUNICIPALITY WATER SUPPLY SYSTEM
}

\author{
Stipe Celan ${ }^{1}$, Zora Pilic ${ }^{2}$ \\ Faculty of Health Studies, Bijeli Brijeg bb, 88000 Mostar \\ Faculty of Natural Sciences, Mathematics and Education, Matice hrvatske bb, 88000 Mostar
}

\begin{abstract}
INTRODUCTION: Health monitoring of drinking water includes: a local inspection and maintenance of water supply facilities, physico-chemical and microbiological analysis. Water supply system of Livno municipality is taken as an example of the implementation of health surveillance.

Aim: To show the importance and significance of the implementation of health surveillance in the case of water supply system of the Livno Municipality.

Materials and Methods: This paper is written using the retrospective study, based on physico-chemical and microbiological analysis of drinking water of water supply system of the Livno Municipality. Analyses refer to the period from January 1, 2013 to January 1, 2014.

Results: Physical-chemical parameters from the source to the end point of the water supply system are clean and almost identical. Most microbiological samples taken at the source (raw water) that is not disinfected, are microbiologically positive what represents a permanent risk of contamination. After the disinfection process all the samples taken during the year from the city's faucets had values that were within the permissible concentrations.

Conclusion: Water supply system of the Livno Municipality shows the correct example of drinking water health monitoring.
\end{abstract}

Keywords: Health surveillance, water supply system of Livno municipality

Correspondence:

Stipe Celan, Bachelor of sanitary engineering

stipecelan@gmail.com 